\title{
Pelatihan Penyusunan Laporan Keuangan di Era Bisnis Digital Pada SMK Globe National Plus
}

\author{
Hermaya Ompusunggu1 \\ Fakultas Ilmu Sosial Humaniora, Universitas Putera Batam, Hermaya@puterabatam.ac.id \\ Lismayasari2 $^{2}$ \\ Fakultas Ilmu Sosial Humaniora, Universitas Putera Batam, Lismaya@Puterabatam.ac.id \\ Nurul Fazirah ${ }^{3}$ \\ Fakultas Ilmu Sosial Humaniora, Universitas Putera Batam, nurulfazirah129@gmail.com
}

\begin{abstract}
Abstrak
Berdasarkan hasil survey dan wawancara dengan Kepala Sekolah SMK National Plus, Bapak Sobri, Permasalahan yang dihadapi di era digital ini adalah dalam mempersiapkan siswa/i jurusan akuntansi siap untuk memasuki dunia kerja/dunia industri, untuk mempersiapkan para siswa tersebut maka perlu diberikan pelatihan penyusunan laporan keuangan di era bisnis digital. Karena hampir seluruh perusahaan dalam menyusun laporan keuangan nya sudah menggunakan sistem aplikasi. Dengan pelatihan penyusunan laporan keuangan di era bisnis digital ini, diharapkan Lulusan SMK Globe national Plus jurusan akuntansi siap memasuki dunia usaha/dunia industri. Sasaran yang menjadi objek pengabdian ini adalah siswa/i kelas XII jurusan akuntansi. Metode yang digunakan adalah observasi, survey ke sekolah dan wawancara dengan kepala sekolah. Pendidikan diberikan dengan memberikan pelatihan terkait dengan topik yang dibutuhkan oleh mitra dalam mempersiapkan siswa/i siap pakai di dunia usaha/dunia industri. Luaran hasil yang diperoleh adalah pemahaman semua siswa/i dalam menyusun laporan keuangan dengan menggunakan aplikasi serta menambah ilmu pengetahuan.
\end{abstract}

Kata Kunci: Laporan Keuangan, Bisnis Digital, Sekolah Globe National Plus

\begin{abstract}
Based on the results of a survey and interview with the Principal of the National Plus Vocational School, Mr. Sobri, the problem faced in this digital era is in preparing students/i majoring in accounting to be ready to enter the world of work/industry, to prepare these students, training in report preparation needs to be given finance in the digital business era. Because almost all companies in preparing their financial statements are already using an application system. With this training in preparing financial statements in the digital business era, it is hoped that graduates of the Globe National Plus SMK majoring in accounting are ready to enter the business/industrial world. The object of this service is grade XII students majoring in accounting. The method used is observation, survey to school and interview with the principal. Education is given by providing training related to topics needed by partners in preparing students ready for use in the business world/industrial world. The output results obtained are the understanding of all students in preparing financial reports by using applications and adding knowledge.
\end{abstract}

Keywords: Financial Statements, Digital Business, Globe National Plus Schools 


\section{Pendahuluan}

Di era digital dan perkembangan teknologi seperti sekarang ini, arus informasi berjalan begitu cepat. Teknologi internet telah mengubah pandangan seseorang dalam mendapatkan informasi, termasuk dalam dunia akuntansi dan bisnis. Perkembangan teknologi mengubah bisnis menjadikan tidak banyaknya sumber daya manusia yang dibutuhkan dalam bisnis, termasuk staf akuntansi. Hal ini mengakibatkan profesi akuntan underestimate terkait dampak teknologi terhadap pekerjaan akuntan. Ini menjadikan tantangan berat yang harus dijawab. Potensi teknologi menggantikan peran profesi akuntan hanya menunggu waktu. Peran akuntan akan bersifat strategis dan konsultatif. (Mutmaimah P, 2017)

Maka dari itu akuntan perlu memiliki sertifikasi misalnya fasih berteknologi, supaya mampu bertahan dalam bersaing. Seorang akuntan juga harus memiliki strategi, diantaranya penguasaaan soft skill baik interpersonal skills maupun intra-personal skills, Business understanding skilss dan tecnical skills agar mampu menjawab tantangan di era digital ini (Nurhaidah, 2015). Sangatlah tidak sempurna apabila kita hanya memperlengkapi para siswa dengan pengetahuan teoritis tanpa ada tambahan pengetahuan di bidang teknologi informasi bagi para siswa jurusan akuntansi. Apalagi jika pihak sekolah tidak bisa memperlengkapi tenaga pendidik dengan keahlian siap kerja, maka masa depan sekolah juga masih menjadi tanda tanya besar di kemudian hari untuk bisa eksis dalam dunia pendidikan.

Permasalahan seperti ini juga tim pengabdi temukan di SMK Globe National Plus jurusan Akuntansi, sesuai dengan hasil survey dan wawancara dengan Kepala Sekolah Bapak Sobri. Sangatlah tidak sempurna apabila guru hanya memperlengkapi para siswa dengan pengetahuan teoritis tanpa ada tambahan pengetahuan di bidang teknologi informasi bagi para siswa jurusan akuntansi. Apalagi jika pihak sekolah tidak bisa memperlengkapi tenaga pendidik dengan keahlian siap kerja, maka masa depan sekolah juga masih menjadi tanda tanya besar di kemudian hari untuk bisa eksis dalam dunia pendidikan.

Atas dasar itulah program pengabdian kepada masyarakat ini dilakukan guna menyelesaikan permasalahan yang dihadapi SMK Globe National Plus dalam mempersiapkan lulusan jurusan akuntansi yang siap bekerja dan mampu menyusun laporan keuangan di era bisnis digital.

\section{Latar Belakang}

SMK Globe National Plus merupakan salah satu sekolah swasta yang menghasilkan lulusan di bidang akuntansi, Rekayasa Perangkat Lunak dan Pemasaran. SMK Globe National Plus beralamat di Simp. Basecamp Batu Aji, Batam. Seperti semboyan “SMK Bisa" maka SMK Globe National Plus juga diharapkan bisa menghasilkan lulusan jurusan akuntansi bisa dan siap memasuki dunia usaha/dunia industri. Untuk itu dibutuhkan tenaga pendidik yang profesional untuk mendidik para siswa yang mampu bersaing. Untuk melengkapi itu maka diberikan pelatihan penyusunan laporan keuangan di era bisnis digital pada SMK Globe National Plus Batam. Maka 
dari itu diharapkan semua orang dapat menjadi bagian dari perubahan tersebut. Hal ini juga merupakan tekanan untuk institusi pendidikan agar membuat kurikulum yang relevan bagi siswa akuntansi untuk menyesuaikan dengan konektivitas digital sehingga diharapkan para lulusan yang akan menjadi akuntan mampu beradaptasi di era digital saat ini.

Revolusi Industri dan globalisasi seakan menjadi satu kesatuan yang tak terlepas dari kehidupan manusia. Seperti yang telah diketahui banyak orang bahwa zaman sekarang sudah menggunakan teknologi yang lebih canggih mulai dari bidang industri sampai perdagangan menggukan teknologi (Rosardi, R.G , 2018). Banyak yang mengatakan bahwa globalisasi dan revolusi industri mempunyai keuntungan, tetapi tidak sedikit pulayang menganggap bahwa hal itu merugikan. Contohnya sudah terlihat di seluruh dunia termasuk indonesia. Indonesia juga terimbas efek globalisasi dan beberapa waktu yang lalu, pemerintah mencanangkan revolusi industri 4.0 yang menggantikan revolusi-revolusi sebelumnya.

Revolusi ini diklaim mampu bersaing di tingkat internasional tetapi permasalahan yang ada di negeri ini belum terselesaikan. Masih banyak hal yang harus diselesaikan mulai dari SDM, manajemen pemerintah, dan pelaku-pelaku yang terlibat dalam revolusi industri ini. Sehingga, Indonesia mampu bersaing di tingkat internasional tanpa mengalami masalah-masalah yang timbul di Indonesia. Seorang akuntan harus aware terhadap perkembangan revolusi industri 4.0 dengan melihat kesempatan yang ada (Mutmaimah P, 2017). Begitu juga dengan siswa jurusan akuntansi siap tidak siap harus siap dalam menerima perubahan dan perkembangan teknologi. Pekembangan teknologi informasi telah memfungsikan dirinya sebagai penyedia informasi yang luas.

Dengan demikian, ada banyak sumber informasi (sumber) belajar bagi para siswa, maka pendidikan di sekolah harus diselaraskan dengan berupaya sedemikian rupa sehingga hasilnya dapat menjadi dasar bagi siswa untuk mengembangkan di luar sekolah.(Nasiwan, Y.S ,2016). Dengan semboyan " SMK Bisa" diharapkan Lulusan SMK jurusan akuntansi bisa dan siap memasuki dunia usaha/dunia industri. Untuk itu dibutuhkan tenaga pendidik yang profesional untuk mendidik para siswa yang mampu bersaing. Untuk melengkapi itu maka diberikan pelatihan penyusunan laporan keuangan di era bisnis digital pada SMK Globe National Plus Batam.

Pengaruh globalisasi ini lah yang menuntut lembaga pendidikan untuk menghasilkan lulusan yang siap pakai/kerja di dunia usaha/industri. Hal ini merupakan tantangan buat SMK Globe National Plus dalam mempersiapkan lulusannya dalam menghadapi era industri 4.0 ini, maka dari itu SMK Globe National Plus merasa perlu dilakukan pelatihan penyusunan laporan keuangan di era bisnis digital khususnya untuk kelas XII jurusan akuntansi. 


\section{Tujuan}

Tujuan dari pelaksanaan pengabdian ini adalah untuk menyelesaikan permasalahan yang dihadapi SMK Globe National Plus dalam menyiapkan lulusan akuntansi yang siap bekerja dan mampu menyusun laporan keuangan di era bisnis digital.

\section{Manfaat}

Setelah mengikuti pelatihan ini siswa/i memiliki bekal dalam menghadapi revolusi industri 4.0 khususnya dalam penyusunan laporan keuangan di era bisnis digital ini.

\section{Metode}

Untuk memperoleh manfaat dari pengabdian kepada masyarakat ini serta dapat diimplementasikan, maka metode yang ditawarkan dalam pengabdian ini adalah sebagai berikut:

1. Langkah pertama survei ke lokasi

Tim Dosen melakukan kunjungan dan peninjauan ke SMK National Globe yang beralamat di Simp. Basecamp, Batu Aji.

2. Tim dosen akan memberikan materi tentang Penyusunan laporan keuangan di era bisnis digital.

3. Peserta akan diberikan pelatihan Penyusunan laporan keuangan di era bisnis digital

4. Peserta pembinaan akan diberikan kesempatan untuk mendiskusikan permasalahan yang dihadapi terkait dengan pengoperasian keuangan ini akan dievaluasi agar diketahui seberapa jauh keberhasilan dari kegiatan pelatihan ini.

Tolak ukur Kegiatan pembinaan tentang pendidikan ini dapat dilihat dari Tabel 1. Berikut:

Tabel 1. Evaluasi pelaksanaan kegiatan

\begin{tabular}{lll}
\hline \multicolumn{1}{c}{ Tujuan } & Indikator ketercapaian & Tolak ukur \\
\hline $\begin{array}{l}\text { Peserta mendapatkan ilmu } \\
\text { dan pengetahuan mengenai }\end{array}$ & Peserta memahami dan & Peserta dapat \\
penyusunan laporan & mengenai penyusunan & mengaplikasikan tentang \\
keuangan di era bisnis digital & laporan keuangan di era & $\begin{array}{l}\text { pengelolaan penyusunan } \\
\text { laporan keuangan dengan }\end{array}$ \\
& bisnis digital. & tecknologi. \\
$\begin{array}{l}\text { Peserta mendapatkan ilmu } \\
\text { dan pengetahuan mengenai }\end{array}$ & Peserta memahami dan & Peserta bisa menjelaskan \\
Financial technologi dan & financial teknologi dan peran \\
peran akuntan & akuntan & tentang bagaimana Financial \\
& & \\
\hline
\end{tabular}


Pengabdian ini dilksanakan pada tanggal 16 Juli - 15 Agustus 2019 di SMK Globe National Plus yang beralamat di Simp. Basecamp, Btu Aji, Batam.

\section{Hasil dan Pembahasan}

\section{Hasil Pengabdian}

Berdasarkan pembinaan/pelatihan yang telah tim pengabdi lakukan pada SMK Globe National Plus yang beralamat di Simp. Basecamp Batu Aji Batam, benar-benar diharapkan dapat memberikan dampak yang positif kepada para masyarakat setempat dan juga kepada tim pengabdi yang melakukan pelatihan/pembinaan tersebut, atau secara rinci hasil yang dicapai dari pelaksanaan pemberdayaan tersebut dapat diuraikan antara lain adalah sebagai berikut:

1. Peserta mendapatkan ilmu dan pengetahuan mengenai penyusunan laporan keuangan di era bisnis digital.

2. Peserta mendapatkan ilmu dan pengetahuan mengenai Financial technologi dan peran akuntan.

3. Peserta memahami dan memiliki pengetahuan mengenai penyusunan laporan keuangan di era bisnis digital.

4. Peserta memahami dan memiliki pengetahuan financial teknologi dan peran akuntan.

5. Peserta dapat mengaplikasikan tentang pengelolaan penyusunan laporan keuangan dengan technologi.

Pembinaan yang dilakukan pada siswa SMK Globe National Plus jurusan akuntansi mengenai penyusunan laporan keuangan di era bisnis digital, telah dapat memberikan dampak positif kepada para peserta dan juga kepada tim dosen dan mahasiswa yang melakukan pembinaan. Secara lebih rinci hasil yang dicapai dalam pelaksanaan pembinaan tersebut dapat diuraikan antara lain sebagai berikut:

1. Terjalinnya kerjasama antara Universitas Putera Batam dengan SMK Globe National Plus.

2. Peserta diberikan pembinaan mengenai penyusunan laporan keuangan di era bisnis digital.

3. Menambah wawasan sisa dalam hal penyusunan laporan keuangan di era bisnis digital.

4. Mengembangkan dan berbagi ilmu pengetahuan kepada masyarakat khususnya siswa SMK Globe National Plus.

Selama memberikan pembinaan mengenai penyusunan laporan keuangan di era bisnis digital, tim dosen telah memberikan materi tentang revolusi industri 4.0, Financial Teknologi dan Peran Akuntan.

Pada hari pertama tim dosen memberikan pemahaman mengenai Revolusi Industri 4.0 dengan materi sebagai berikut: 
Pengertian Revolusi Industri 4.0, Prinsip, dan Tantangan Revolusi Industri 4.0 Lengkap - Revolusi Industri 4.0 adalah suatu tren otomasi dan pertukaran data terkini dalam teknologi pabrik mencakup sistem siber-fisik, internet untuk segala, komputasi awan dan komputasi kognitif. Secara singkat, pengertian revolusi industri 4.0 adalah tren di dunia industri yang menggabungkan teknologi otomatisasi dengan teknologi cyber (Prasetyo, H., \& Sutopo, W. 2018). Revolusi Industri 4.0 merupajan suatu fase keempat dari perjalanan sejarah revolusi industri yang akan dimulai pada abad ke-18. Indonesia juga akan mengalami bonus demografi pada tahun 2030-2040, yaitu penduduk dengan usia produktif lebih banyak dibandingkan dengan penduduk non produktif.Revolusi Industri 4.0 dibangun diatas Revolusi Industri 3.0 atau ketiga yang disebut juga Revolusi Digital, yang ditandai oleh proliferasi komputer dan otomatisasi pencatatan disemua bidang.Pada hari kedua tim pengabdi memberikan materi mengenai Financial Technologi dan Peran Akuntan dengan materi sebagai berikut: Perkembangan bisnis startup yang terus meningkat setiap tahunnya membuat para startup berlomba-lomba untuk mengenalkan produk mereka ke masyarakat. Salah satu yang kini sedang meningkat pesat adalah Fintech (Financial Technology). Munculnya Fintech di Indonesia bertujuan untuk memudahkan masyarakat dalam melakukan transaksi keuangan secara online, meningkatkan literasi keuangan, dan mewujudkan inklusi keuangan di indonesia. Perusahaan Fintech di Indonesia yang sekarang didominasi oleh startup dengan potensi yang besar. Karena itu, Fintech berkembang cepat ke berbagai sektor seperti ke startup pembayaran (payment gateway), manajemen keuangan (wealth management), pembiayaan (crowdfunding), peminjaman (lending) dan lainnya. Kegiatan Pengabdian seperti terlihat pada dibawah ini:

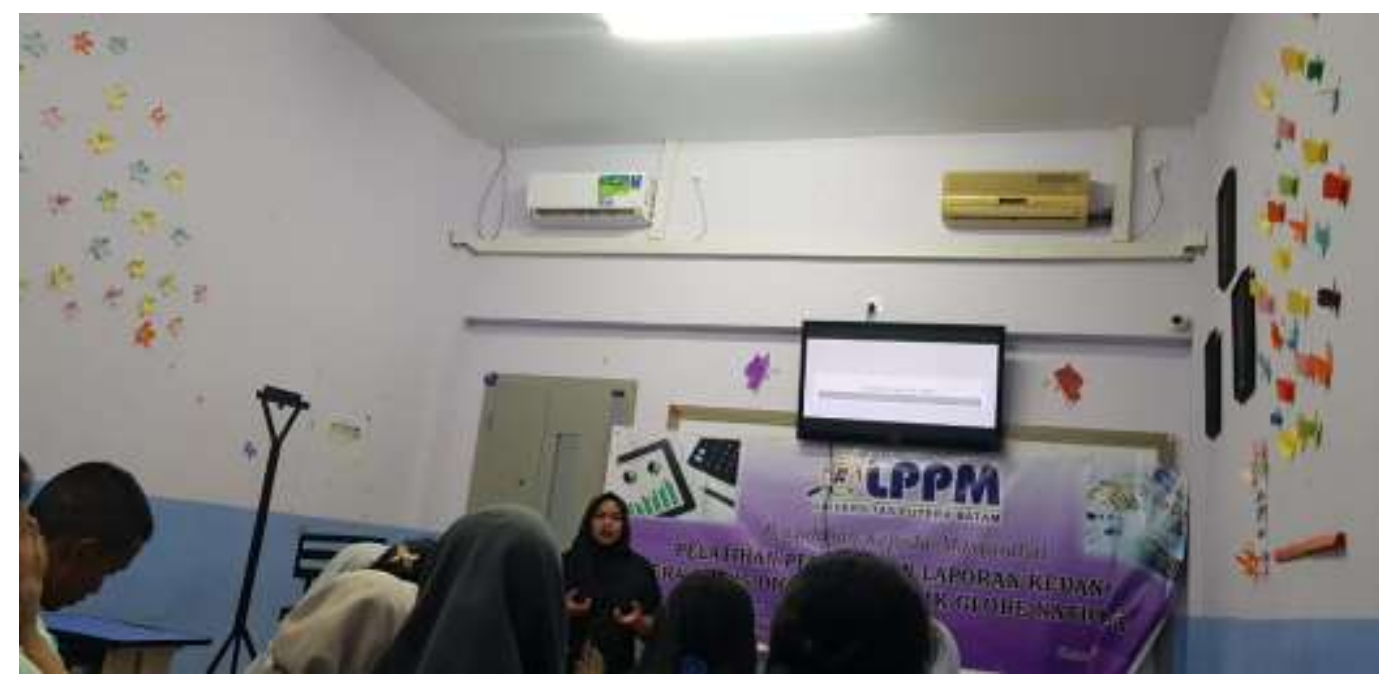

Gambar 1. Foto kegiatan Pengabdian

\section{Pembahasan}

Suksesnya kegiatan pembinaan yang diberikan kepada siswa SMK Globe National Plus Batam, telah menjadi kebanggan tersendiri bagi tim pengabdi. Beberapa hal yang 
dilaksanakan oleh tim dosen untuk menyukseskan kegiatan pelatihan secara garis besar dapat dijelaskan sebagai berikut:

1. Survey ke lokasi pengabdian dilaksanakan

2. Mengumpulkan dana untuk acara pengabdian seperti biaya mencetak spanduk dan konsumsi

3. Mencetak spanduk

4. Belanja untuk konsumsi selama acara pengabdian

Kegiatan pengabdian yang dilaksanakan di SMK Globe National Plus Batam memberikan respon positif dan dapat diterima dengan baik oleh pihak SMK Globe National Plus Batam. Siswa akuntansi antusias mengikuti kegiatan pembinaan yang pengabdi lakukan. Dengan dilaksanakannya kegiatan pembinaan ini, pemahaman siswa SMK SMK Globe National Plus khususnya jurusan akuntansi semakin bertambah. Dalam kegiatan ini, sebelum memberikan materi dan pemahaman mengenai penyusunan laporan keuangan di era bisnis digital, terlebih dahulu tim pengabdi melakukan tanya jawab kepada siswa jurusan akuntansi. Dengan cara ini, maka akan dapat dengan mudah memberikan pemahaman kepada siswa tersebut. Penjelasan juga difokuskan pada materi yang kurang dipahami.

\section{Simpulan dan Rekomendasi}

Berdasarkan pembahasan pembinaan yang dilakukan di SMK Globe National Plus Batu Aji Batam di atas, maka disimpulkan sebagai berikut: Peserta memahami mengenai penyusunan laporan keuangan di era bisnis digital dan Peserta pengabdian mampu memahami dan mengerjakan latihan terkait dengan materi pengabdian yang telah diberikan. Untuk harapan kedepannya Siswa SMK Globe National Plus jurusan akuntansi disarankan meningkatkan pemahaman siswa mengenai Financial technologi. Hal ini berguna untuk membantu siswa dalam menghadapi era revolusi industri 4.0 dan untuk lebih sering dan lebih banyak lagi mengerjakan soal-soal latihan supaya pemahaman mereka menjadi sempurna.

\section{Acknowledgements}

Dalam proses pengabdian kepada masyarakat ini tim pengabdi memperoleh banyak bantuan dan dukungan yang sangat berharga dari berbagai pihak, untuk itu kami mengucapkan terima kasih dan rasa hormat kami kepada:

1. Universitas Putera Batam melalui LPPM Universitas Putera Batam atas dukungan yang diberikan sehingga terlaksananya pengabdian kepada Masyarakat ini

2. Kepala SMK Globe National Plus beserta guru dan siswa yang sudah meluangkan waktunya untuk mensukseskan pengabdian ini.

3. Semua pihak yang sudah membantu yang tidak bisa tim sebutkan satu persatu. Untuk semua pihak yang sudah banyak membantu, semoga Allah SWT membalas kebaikan Bapak/Ibu dengan berlipas Ganda. 


\section{Daftar Pustaka}

Mutmainah, P. (2017). Sejarah dan Proses Globalisasi. Ilmu Sekolah.blogspot.som, 2 (sejarah dan proses globalisasi), 24.

Nasiwan, Y.S (2016). Teori-Teori Sosial Indonesia. Seri Teori-Teori Sosial Indonesia, 67.

Nurhaidah, M.I . (2015). Dampak Pengaruh Globalisasi Bagi Kehidupan Bangsa Indonesia. JurnalPesona Dasar, 3, 1-14.

Prasetyo, H., \& Sutopo W. (2018). Industri 4.0: Telaah Klasifikasi Aspek dan Arah Perkembangan Riset. Jati Undip : Jurnal Teknik Industri, 13, 17-26.

R.G Rosardi. (2018). Globalisasi. Essay. 